\title{
Effect of heat stress on blood parameter, carcass and meat quality of Black Bengal goat
}

\author{
MA Hashem*1, MM Hossain¹, MS Rana, MM Hossain¹, MS I slam², NG Saha4 \\ ${ }^{1}$ Department of Animal Science, Bangladesh Agricultural University, Mymensingh 2202, Bangladesh; \\ ${ }^{2}$ Bangladesh Livestock Research Institute, Savar, Dhaka; ${ }^{3}$ Agrotechnology Discipline, Khulna University, \\ Khulna; ${ }^{4}$ Department of Animal Science and Nutrition, Patuakhali Science and Technology University, \\ Khanpura, Babugonj, Barisal, Bangladesh
}

\begin{abstract}
The research was conducted to study the effect of heat stress on blood parameter, carcass characteristics and meat quality of the Black Bengal goat. Nine goats were randomly and equally divided into three groups having almost same age and weight. Three groups were divided as zero hour $\left(T_{0}\right)$, four hours $\left(T_{4}\right)$ and eight hours $\left(T_{8}\right)$ of heat exposure. The $T_{0}$ group were not exposed to heat stress, the $T_{4}$ and $T_{8}$ group were exposed to heat by keeping them at outside for 4 (four) hours and 8 (eight) hours from 9.00 AM to $1.00 \mathrm{PM}$ and from 9.00 AM to $5.00 \mathrm{PM}$, respectively. Temperaturehumidity index (THI) was calculated as 26.88 indicating all the experimental animals were in extreme severe heat stress. The blood parameter such as RBC, PCV\%, Hb\%, WBC was significantly $(p<0.01)$ higher in $T_{8}$ group than those of $T_{4}$ and $T_{0}$ groups. There was also significant $(p<0.05)$ effect of heat stress on $\mathrm{pH}$ of the meat from different groups of the Black Bengal goats. By-products e.g., blood, pluck, spleen and kidney, and cooking loss were significantly $(p<0.01)$ increased with the increase of the heat, but no significant differences were observed for pre-slaughter parameters, carcass weight, drip loss, dressing percentage, and proximate composition of the goat meat for $\mathrm{DM}, \mathrm{CP}$ and Ash, while the EE significantly $(p<0.05)$ differed among the heat treated groups. Heat stress significantly affected the blood parameter, cooking loss, $\mathrm{pH}$, by-product of goats rather than non heat stressed group. It indicates that heat stress limits the qualitative and quantitative production characteristics of goat meat.
\end{abstract}

Key words: Blood parameter, goat carcass, heat stress, meat by-product

Bangladesh Animal Husbandry Association. All rights reserved.

Bang. J. Anim. Sci. 2013. 42 (1): 57-61

\section{I ntroduction}

Goats play an important role in the subsistence economy of smallholder and provide 1.31 million MT of meat to the people of Bangladesh (FAO, 2009). Goat is found in almost all the villages, and plays an important role in nutrition, income generation and employment for the rural people of Bangladesh. High environmental temperature challenges the animal's ability to maintain energy, thermal, water, hormonal and mineral balance. Heat stress stimulates excessive production of free radicals (superoxide anion radicals, hydroxyl radical, hydrogen peroxide and singlet oxygen) which are continuously produced in the course of normal aerobic metabolism (Bernabucchi et al. 2001) and these free radicals can in turn damage healthy cells if they are not eliminated. Exposure of animals to heat stress activates the hypothalamopituitary-adrenal axis (Abilay et al. 1975) and estimation of concentrations of hormones such as thyroxin, cortisol, and prolactin could be one of the important indicators for assessment of stress in animals.
High ambient temperature and humidity are the major constraint on sheep productivity in tropical and sub-tropical areas (Marai et al. 2007). Increased body temperature and respiration rate are the most important signs for heat stress in goat. These include the aberration of reproductive functions (Roth et al. 2002), oxidative stress and enzymatic dysfunction (David et al. 2001), electrolyte imbalances (West et al. 1991), reduced meat quality (Kadima et al. 2004), and severe economic losses resulting from increased mortalities and decreased overall animal performance (Hahn and Mader 1997). Normal body temperature is essential for physiological adjustment and to prevent hyperthermia (AlHaidary 2000; Lowe et al. 2001). Animal under heat stress may fail to adjust themselves resulting lower animal productivity and a tremendous economic loss for the goat industry. There is a lack of information related to the effect of heat stress on the blood parameter, carcass characteristics and meat quality of goat in Bangladesh. Therefore, the present study was conducted to investigate the effect of heat stress on blood parameters, carcass characteristics and meat quality of the Black Bengal goat. 


\section{Materials and Methods}

The experiment was conducted from April to July, 2011 at the Goat, Sheep and Horse farm of Bangladesh Agricultural University, Mymensingh. Nine Black Bengal female goats were randomly selected for the experiments, and equally divided into three groups almost having similar age and weight. Means of estimating the severity of heat stress was proposed using both ambient temperature and relative humidity, termed as the temperature humidity index (THI) (LPHSI, 1990; Marai et al. (2007). When temperature is measured $\left({ }^{0} \mathrm{~F}\right)$, the equation to determine $\mathrm{THI}$ is as follows (LPHSI, 1990): $\mathrm{THI}=\mathrm{db}{ }^{0} \mathrm{~F}-\{(0.55-$ $\left.0.55 \mathrm{RH})\left(\mathrm{db}{ }^{0} \mathrm{~F}-58\right)\right\}$ where $d b{ }^{0} \mathrm{~F}$ is the dry bulb temperature in ${ }^{0} \mathrm{~F}$ and $\mathrm{RH}$ is the relative humidity $(\mathrm{RH} \%) / 100$, for sheep and goats. The obtained values indicate the following: values $<82=$ absence of heat stress; 82 to $<84=$ moderate heat stress; 84 to $<86=$ severe heat stress and over $86=$ extreme severe heat stress (LPHSI 1990). When the temperature is expressed in ${ }^{\circ} \mathrm{C}$, the equation of Marai et al. (2001) changes as follows: $\mathrm{THI}=\mathrm{db}{ }^{0} \mathrm{C}-\{(0.31$ $\left.-0.31 \mathrm{RH})\left(\mathrm{db}{ }^{0} \mathrm{C}-14.4\right)\right\}$ where $\mathrm{db}{ }^{0} \mathrm{C}$ is the dry bulb temperature $\left({ }^{\circ} \mathrm{C}\right)$ and $\mathrm{RH}$ is the relative humidity $(\mathrm{RH} \%) / 100$. The values obtained indicate the following: $<22.2=$ absence of heat stress; 22.2 to $<23.3=$ moderate heat stress: 23.3 to $<25.6=$ severe heat stress and 25.6 and more $=$ extreme severe heat stress (Marai et al., 2001). In the present study during experimental period average temperature was $26.88^{\circ} \mathrm{C}$ and average relative humidity was $87.83 \%$. Hence, THI value was 28.17 which indicate all the experimental animals were in severe heat stress (Marai et al. 2007).

These were made as 0 hour heat exposure group or control group (without heat exposure in stall feeding), 4 hours heat exposure group (09 am to $01 \mathrm{pm}$ heat exposure in grazing) and 8 hours heat exposure group (9.00 am to $05 \mathrm{pm}$ heat exposure in grazing). That is these groups were as zero hour $\left(T_{0}\right)$, four hours $\left(T_{4}\right)$ and eight hours $\left(T_{8}\right)$ of heat exposure. Goats of these groups were kept in the room separated with fence and were given two months for their psychological and physiological adjustment. The animals in each group was supplied an adequate amount of roughage and concentrate along with ad libitum clean drinking water daily. The initial body weight for each animal was recorded and then weighing was carried out by using weigh band for every week at the same time before morning feeding.
The data of Ambient Temperature and Relative Humidity for the experimental days were collected from Meteorological Centre, Bangladesh Agricultural University, Mymensingh. Twenty (20) $\mathrm{g}$ of meat sample was taken for the chemical analyses (proximate composition), and 5, 60 and $60 \mathrm{~g}$ were also taken for the determination of $\mathrm{pH}$, drip loss and cooking loss, respectively. All these samples were collected from the same region of each slaughtered goat, and then weighed and packed separately. Proximate compositions such as dry matter, crude protein, ether extract and ash were estimated using the method by AOAC, 1995. Dressing percentage and eye muscle area (EMA) were also estimated. The $\mathrm{pH}$ was measured using by $\mathrm{pH}$ meter (Corning model 250). Drip loss and cooking loss was measured using the principle of Honikel (1998). Blood was collected from jugular vein of the animals by the method described by Schalm et al. (1975).

Data were analyzed statistically using the analysis of variance technique using SAS statistical computer package program (1998) in accordance with the principle of Completely Randomized Design (CRD). Duncan's Multiple Range Test was done to compare variations between treatments.

\section{Results and Discussion}

\section{Effect of heat stress on blood parameter}

Table 1 shows that the blood parameters the RBC and WBC were 9.38 \pm 0.59 and $8.06 \pm 0.26$, $9.85 \pm 0.45$ and $8.59 \pm 0.65$, and $10.18 \pm 0.50$ and $9.0 \pm 0.30$ for $T_{0}, T_{4}$ and $T_{8}$, respectively. PCV\% and $\mathrm{Hb} \%$ were $27.65 \pm 0.56$ and $8.7 \pm 0.33$, $28.06 \pm 0.85$ and $9.08 \pm 0.54$, and $29.10 \pm 1.50$ and $10.0 \pm 0.45$ for $T_{0}, T_{4}$ and $T_{8}$, respectively.

The amount of RBC, PCV\%, $\mathrm{Hb} \%, \mathrm{WBC}$ was significantly higher $(p<0.01)$ in $T_{8}$ group than those of $T_{4}$ and $T_{0}$ group, respectively (Table 1 ). $T_{4}$ group were significantly higher $(p<0.01)$ than that of $T_{0}$ group. In the present study, both PCV and haemoglobin $(\mathrm{Hb})$ were increased in the $\mathrm{T}_{4}$ and $\mathrm{T}_{8}$ which was not in agreement with the findings of Srikandakumar et al. (2003) in sheep and Abdel-Samee (1991) in goats. These increase of hemoglobin and PCV levels might be due to either increased of free radicals on the RBC membrane, which is rich in lipid content, and ultimate lysis of RBC or adequate nutrient availability for hemoglobin synthesis as the animal consumed more feed or decrease voluntary intake under heat stress (Srikandakumar et al. 2003). 
Table 1. Effect of heat stress on blood parameter (Mean \pm SD)

\begin{tabular}{lccc}
\hline Parameter & $\mathrm{T}_{0}$ & $\mathrm{~T}_{4}$ & $\mathrm{~T}_{8}$ \\
\hline RBC (million/ & $9.38^{\mathrm{c}}$ & $9.85^{\mathrm{b}}$ & $10.18^{\mathrm{a}}$ \\
cubic mm) & \pm 0.59 & \pm 0.45 & \pm 0.50 \\
\hline WBC (Thousand/ & $8.06^{\mathrm{c}}$ & $8.59^{\mathrm{b}}$ & $9.0^{\mathrm{a}}$ \\
cubic mm) & \pm 0.26 & \pm 0.65 & \pm 0.30 \\
\hline \multirow{2}{*}{ PCV\% } & $27.65^{\mathrm{c}}$ & $28.06^{\mathrm{b}}$ & $29.10^{\mathrm{a}}$ \\
& \pm 0.56 & \pm 0.85 & \pm 1.50 \\
\hline \multirow{2}{*}{ Hb (g/percent) } & $8.7^{\mathrm{c}}$ & $9.1^{\mathrm{b}}$ & $10.0^{\mathrm{a}}$ \\
& \pm 0.33 & \pm 0.54 & \pm 0.45
\end{tabular}

Means with different superscript in the same raw differ significantly $(p<0.01), T_{0}$, zero hour of heat exposure, $T_{4}$, four hours of heat exposure; $T_{8}$, eight hours heat exposure

\section{Pre-slaughter and carcass parameters of goat}

Table 2 represents the pre-slaughter parameter of the Black Bengal goat. I nitial and slaughter weight was $12.3 \pm 0.60$ and $12.5 \pm 0.57,12.33 \pm$ 0.33 and $12.83 \pm 0.33$, and $12.66 \pm 0.88$ and $13.0 \pm 0.57 \mathrm{~kg}$ for $T_{0}, T_{4}$ and $T_{8}$, respectively. Likewise, the body length and heart girth was $47.66 \pm 1.20$ and $51.00 \pm 0.57,48.33 \pm 0.88$ and $52.33 \pm 0.33$, and $48.66 \pm 1.85$ and $53.33 \pm 1.76$ $\mathrm{cm}$ for $\mathrm{T}_{0}, \mathrm{~T}_{4}$ and $\mathrm{T}_{8}$, respectively. No significant differences were observed for body weight, length and heart girth among the treatment groups. These findings were consistent with the values described by Hussain (1993). The mean body weight was slightly higher than that of the findings of Singh et al. (1981).

Table 2 shows that the carcass weight were 4.77 $\pm 0.14,5.50 \pm 0.28$ and $5.66 \pm 0.44 \mathrm{~kg}$ with a dressing percentage of $40.28 \pm 10.86,42.81 \pm$ 1.41 and $40.85 \pm 0.63$ for $T_{0}, T_{4}$ and $T_{8}$, respectively. Rib eye area was $9.25 \pm 0.337,11.77$ \pm 0.81 and $11.33 \pm 1.84 \mathrm{~cm}^{2}$ for $T_{0}, T_{4}$ and $T_{8}$, respectively. There were no significant differences among the carcass weight, dressing percentage and rib eye area.

Table 2 demonstrates the $\mathrm{pH}$, drip loss and cooking loss of meat. The pH of meat was $6.16 \pm$ $0.014,6.18 \pm 0.016$ and $6.30 \pm 0.045$ for $T_{0}, T_{4}$ and $T_{8}$, respectively. Percentage of drip loss and cooking loss were $12.38 \pm 0.48$ and $35.77 \pm 0.79$, $11.89 \pm 1.05$ and $41.41 \pm 0.55$, and $13.61 \pm 0.64$ and $42.89 \pm 0.35$ for $T_{0}, T_{4}$ and $T_{8}$, respectively. The significant $(p<0.05)$ difference was observed for heat stress on $\mathrm{pH}$ within the different groups of goats. Similarly, the cooking loss demonstrated highly significant $(p<0.01)$ effect, but drip loss had no significant variation amongst the experimental groups.
Table 2. Effect of heat stress on pre-slaughter and carcass parameters (Mean \pm SD) of goat

\begin{tabular}{|c|c|c|c|c|}
\hline Parameter & $\mathrm{T}_{0}$ & $\mathrm{~T}_{4}$ & $\mathrm{~T}_{8}$ & $\begin{array}{l}\text { Sig. } \\
\text { Level }\end{array}$ \\
\hline $\begin{array}{l}\text { Initial weight } \\
(\mathrm{kg})\end{array}$ & $\begin{array}{c}12.3 \\
\pm 0.60 \\
\end{array}$ & $\begin{array}{l}12.33 \\
\pm 0.33 \\
\end{array}$ & $\begin{array}{l}12.66 \\
\pm 0.88 \\
\end{array}$ & NS \\
\hline $\begin{array}{l}\text { Slaughter weight } \\
(\mathrm{kg})\end{array}$ & $\begin{array}{l}12.5 \\
\pm 0.57\end{array}$ & $\begin{array}{l}12.83 \\
\pm 0.33 \\
\end{array}$ & $\begin{array}{c}13.0 \\
\pm 0.57\end{array}$ & NS \\
\hline $\begin{array}{l}\text { Body length } \\
(\mathrm{cm})\end{array}$ & $\begin{array}{l}47.66 \\
\pm 1.20\end{array}$ & $\begin{array}{l}48.33 \\
\pm 0.88\end{array}$ & $\begin{array}{r}48.66 \\
\pm 1.85\end{array}$ & NS \\
\hline $\begin{array}{l}\text { Heart girth } \\
(\mathrm{cm})\end{array}$ & $\begin{array}{r}51.00 \\
\pm 0.57 \\
\end{array}$ & $\begin{array}{r}52.33 \\
\pm 0.33 \\
\end{array}$ & $\begin{array}{r}53.33 \\
\pm 1.76 \\
\end{array}$ & NS \\
\hline $\begin{array}{l}\text { Carcass weight } \\
(\mathrm{Kg})\end{array}$ & $\begin{array}{c}4.77 \\
\pm 0.14 \\
\end{array}$ & $\begin{array}{c}5.50 \\
\pm 0.28 \\
\end{array}$ & $\begin{array}{c}5.66 \\
\pm 0.44 \\
\end{array}$ & NS \\
\hline Dressing \% & $\begin{array}{c}40.28 \\
\pm 10.86 \\
\end{array}$ & $\begin{array}{c}42.8 \\
\pm 1.41 \\
\end{array}$ & $\begin{array}{l}40.85 \\
\pm 0.63 \\
\end{array}$ & NS \\
\hline $\begin{array}{l}\text { Rib Eye Area } \\
\left(\mathrm{cm}^{2}\right)\end{array}$ & $\begin{array}{r}9.25 \\
\pm 0.337 \\
\end{array}$ & $\begin{array}{r}11.77 \\
\pm 0.81 \\
\end{array}$ & $\begin{array}{r}11.33 \\
\pm 1.84\end{array}$ & NS \\
\hline$p^{H}$ & $\begin{array}{c}6.16^{\mathrm{b}} \\
\pm 0.014 \\
\end{array}$ & $\begin{array}{r}6.18^{\mathrm{b}} \\
\pm 0.016 \\
\end{array}$ & $\begin{array}{c}6.30^{\mathrm{a}} \\
\pm 0.045 \\
\end{array}$ & $*$ \\
\hline $\begin{array}{l}\text { Drip Loss } \\
(\%)\end{array}$ & $\begin{array}{r}12.38 \\
\pm 0.48 \\
\end{array}$ & $\begin{array}{r}11.89 \\
\pm 1.05\end{array}$ & $\begin{array}{l}13.61 \\
\pm 0.64 \\
\end{array}$ & NS \\
\hline $\begin{array}{l}\text { Cooking loss } \\
(\%)\end{array}$ & $\begin{array}{l}35.77^{b} \\
\pm 0.79\end{array}$ & $\begin{array}{l}41.41^{\mathrm{a}} \\
\pm 0.55\end{array}$ & $\begin{array}{l}42.89^{a} \\
\pm 0.35\end{array}$ & $* *$ \\
\hline
\end{tabular}

Means with different superscript in the same raw differ significantly; **, $\mathrm{p}<0.01 ; *, \mathrm{p}<0.05$; NS, non significant, $T_{0}$, zero hour of heat exposure, $T_{4}$, four hours of heat exposure; $T_{8}$, eight hours heat exposure

Table 3. Effect of heat stress on by-products parameter (Mean \pm SD) of goat meat

\begin{tabular}{|c|c|c|c|c|}
\hline $\begin{array}{l}\text { Variables } \\
\text { (g) }\end{array}$ & $\mathrm{T}_{0}$ & $\mathrm{~T}_{4}$ & $\mathrm{~T}_{8}$ & $\begin{array}{c}\text { Sig. } \\
\text { Level }\end{array}$ \\
\hline Blood & $\begin{array}{r}173.33^{b} \\
\pm 6.66\end{array}$ & $\begin{array}{l}240.00^{b} \\
\pm 17.32\end{array}$ & $\begin{array}{l}436.66^{a} \\
\pm 29.62\end{array}$ & $* *$ \\
\hline Head & $\begin{array}{l}606.66 \\
\pm 6.66\end{array}$ & $\begin{array}{r}793.33 \\
\pm 17.63\end{array}$ & $\begin{array}{r}816.66 \\
\pm 55.55\end{array}$ & NS \\
\hline Feet & $\begin{array}{r}198.33 \\
\pm 27.43\end{array}$ & $\begin{array}{r}206.66 \\
\pm 20.27\end{array}$ & $\begin{array}{r}220.00 \\
\pm 32.11\end{array}$ & NS \\
\hline Pluck & $\begin{array}{l}370.00^{b} \\
\pm 25.16\end{array}$ & $\begin{array}{l}423.33^{b} \\
\pm 23.33\end{array}$ & $\begin{array}{l}573.33^{\mathrm{a}} \\
\pm 14.55\end{array}$ & $* *$ \\
\hline Heart & $\begin{array}{l}32.33^{b} \\
\pm 1.45\end{array}$ & $\begin{array}{c}36.66^{\mathrm{ab}} \\
\pm 3.33\end{array}$ & $\begin{array}{l}50.00^{\mathrm{a}} \\
\pm 5.77\end{array}$ & $*$ \\
\hline Spleen & $\begin{array}{l}20.00^{b} \\
\pm 2.88\end{array}$ & $\begin{array}{c}36.66^{\mathrm{ab}} \\
\pm 3.33\end{array}$ & $\begin{array}{l}43.33^{a} \\
\pm 3.33\end{array}$ & $* *$ \\
\hline Liver & $\begin{array}{c}165.00 \\
\pm 8.66 \\
\end{array}$ & $\begin{array}{r}186.66 \\
\pm 17.63 \\
\end{array}$ & $\begin{array}{r}263.33 \\
\pm 47.03 \\
\end{array}$ & NS \\
\hline Kidney & $\begin{array}{l}20.00^{b} \\
\pm 2.88\end{array}$ & $\begin{array}{l}36.66^{\mathrm{a}} \\
\pm 3.33\end{array}$ & $\begin{array}{l}43.33^{a} \\
\pm 3.33\end{array}$ & $* *$ \\
\hline $\begin{array}{l}\text { Lung plus } \\
\text { Trachea }\end{array}$ & $\begin{array}{l}101.66 \\
\pm 14.81\end{array}$ & $\begin{array}{c}103.33 \\
\pm 8.81 \\
\end{array}$ & $\begin{array}{r}136.66 \\
\pm 18.55\end{array}$ & NS \\
\hline
\end{tabular}

Means with different superscript in the same raw differ significantly; $* *, \mathrm{p}<0.01 ; *, \mathrm{p}<0.05$; NS, non significant, $T_{0}$, zero hour of heat exposure, $T_{4}$, four hours of heat exposure; $T_{8}$, eight hours heat exposure 


\section{By-products parameter of goat meat}

The results of by-products as blood, head, feet, pluck, heart, spleen, liver, kidney and lung plus trachea for $T_{0}, T_{4}$ and $T_{8}$ groups are showed in Table 3. The blood, pluck, spleen and kidney had highly significant $(p<0.01)$ difference among different groups. Blood, pluck, spleen and kidney were markedly increased in $T_{8}$ group than those of $\mathrm{T}_{0}$ and $\mathrm{T}_{4}$ groups. Moniruzzaman et al. (2000) showed a little bit higher weight of blood than that of our findings.

\section{Proximate component of goat meat}

The proximate components e.g. dry matter (DM), crude protein $(\mathrm{CP})$, ash and ether extract (EE) of the Black Bengal goat meat for $T_{0}, T_{4}$ and $T_{8}$ groups were summarized in Table 4.

Table 4. Effect of heat stress on proximate composition (Mean \pm SD) of goat meat

\begin{tabular}{lccc}
\hline $\begin{array}{l}\text { Variable } \\
(\%)\end{array}$ & $\mathrm{T}_{0}$ & $\mathrm{~T}_{4}$ & $\mathrm{~T}_{8}$ \\
\hline $\mathrm{DM}$ & $23.82 \pm 0.67$ & $22.95 \pm 0.76$ & $22.77 \pm 0.39$ \\
$\mathrm{CP}$ & $17.00 \pm 1.28$ & $15.60 \pm 1.92$ & $15.85 \pm 0.72$ \\
Ash & $2.37 \pm 0.19$ & $2.83 \pm 0.22$ & $2.54 \pm 0.02$ \\
$\mathrm{EE}$ & $2.60^{\mathrm{a}} \pm 0.17$ & $2.05^{\mathrm{ab}} \pm 0.33$ & $1.26^{\mathrm{b}} \pm 0.44$ \\
\hline
\end{tabular}

Means with different superscript in the same raw differ significantly $(p<0.01), T_{0}$, zero hour of heat exposure, $T_{4}$, four hours of heat exposure; $T_{8}$, eight hours heat exposure

The DM, CP and Ash had no significant difference while heat stress had significantly $(p<0.05)$ effect on EE among the groups. Moniruzzaman et al. (2000) explained that there was an effect of different feeding system on the composition of Black Bengal goat meat and they observed that DM percentage of meat varied significantly $(p>0.05)$ for different feeding systems. Similarly, the EE also significantly $(p<0.01)$ differed due to different feeding systems of goat.

\section{Conclusion}

Heat stress significantly affects blood parameters, cooking loss, $\mathrm{pH}$ and by-products of the Black Bengal goat. Further, in depth study is needed to explore more information to minimize the effect of heat on blood and meat characteristics for both qualitative and quantitative production approaches of goat meat.

\section{References}

Abdel-Samee AM (1991). Detection of heat adaptability of growing lambs in subtropics.
Zagazig Veterinary J ournal, 19:719-731.

Abilay TA, Johnson HD, Madan M (1975). Influence of environmental heat on peripheral plasma progesterone and cortisol during the bovine estrous cycle. J ornal of Dairy Science. 58: 1836-1840.

Al-Haidary A (2000). Effect of heat stress on some thermoregulatory responses of cattle, sheep and goat. Zagazig Veterinary J ournal, 28:101-110.

AOAC (1995). Official methods of analysis, 16th edn. Washington: Association Official Analytical Chemistry.

Bernabuichi AO, Burgoon PW, Boulant JA (2001). Temperature-sensitive properties of rat suprachiasmatic nucleus. American J ournal of Physiology, 281: R706-R715.

David MH, Garry RB, Larry WO, Linjing X, Ronald DM, Carl VG (2001). Mechanisms of circulatory and intestinal barrier dysfunction during whole body hyperthermia. American Journal of Physiology, 280: H509-H521.

FAO, (Food and Agriculture Organization of United Nations) (2009). Production year book. FAO Statistics Series, 57: 211.

Hahn GL, Mader TL (1997). Heat waves and their relation to thermoregulation, feeding behavior and mortality of feedlot cattle. In: Proceedings of the Fifth International Livestock and Environment Symposium. Minneapolis, ASAE, St. Joseph, MO. P. 563567.

Honikel KO (1998). Reference methods for the assessment of physical characteristics of meat. Meat Science, 49: 447-457.

Hussain SS (1993). A study on the productive performance and genetic potentials of black Bengal goats. PhD Dissertation. Department of Animal Breeding and Genetics. Bangladesh Agricultural University, Mymensingh.

Kadima IT, Mahgouba O, Al-Ajmia DS, AlMaqbalya RS, Al-Mugheiryb SM, Bartolomeb DY (2004). The influence of season on quality characteristics of hotboned beef $\mathrm{m}$. longissimus thoracis. Meat Science, 66: 831-836.

Lowe TE, Christian J, Cook JR, Ingram, Phillip (2001). Impact of climate on thermal rhythm in pastoral sheep. Physiology and Behavior, 74: 659-64.

LPHSI (1990). Livestock and Poultry Heat Stress Indices Agriculture Engineering Technology Guide. Clemson University, Clemson, SC 29634, USA.

Marai IFM, Ayyat MS, Abd El-Monem UM (2001). 
Growth performance and reproductive traits at first parity of New Zealand White female rabbits as affected by heat stress and its alleviation, under Egyptian conditions. Tropical Animal Health and Production, 33: 457-462.

Marai IFM, Bahgat LB, Shalaby TH, Abdel-Hafez MA (2007). Fattening performance, some behavioural traits and physiological reactions of male lambs fed concentrates mixture alone with or without natural clay, under hot summer of Egypt. Annals of Arid Zone, 39: 449-460.

Moniruzzaman M, Hashem MA, Akhter S, Hossain MM (2000). Effect of different feeding systems on carcass and non-carcass parameters of black bengal goat. AsianAustralasian Journal of Animal Science, 15: 61-65.

Roth Z, Arav A, Braw-Tal R, Bor A, Wolfenson D (2002). Effect of treatment with folliclestimulating hormone or bovine somatotropin on the quality of oocytes aspirated in the autumn from previously heat-stressed cows. Journal of Dairy Science, 85: 1398- 1405.

Schalm OW, Jam NC, Corrola EJ (1975). Veterinary Haematology. $3^{\text {rd }}$ Edition, Lea and Febiger, Philadelphia, USA.

Singh SP, Mukherjee DK, Prasad B, Mishra HR (1981). Note on body measurements and weights of black and brown-bengal goats. Indian J ournal of Animal Science, 51: 234236.

Srikandakumar A, Johnson EH, Mahgoub O (2003). Effect of heat stress on respiratory rate, rectal temperature and blood chemistry in Omani and Australian Merino Sheep. Small Ruminant Research, 49: 193198.

West JW, Yullinix BO, Sandifer G (1991). Changing dietary electrolyte balance for dairy cows in cool and hot environments. Journal Dairy Science, 74: 1662-1674. 